\begin{tabular}{|c|c|c|}
\hline אוכ & $\begin{array}{c}\text { BIODIK: Jurnal IImiah Pendidikan Biologi } \\
\text { ISSN } 2580-0922 \text { (online), ISSN 2460-2612 (print) } \\
\text { Volume 07, Nomor 04, Tahun 2021, Hal. 107-114 } \\
\quad \text { Available online at: } \\
\text { https://online-journal.unja.ac.id/biodik }\end{array}$ & BIODIK \\
\hline
\end{tabular}

Research Article

\title{
Survei Pembentukan Karakter Mahasiswa Selama Pembelajaran Daring
}

\section{(Survey of Student Character Building During online Learning)}

Ayu Wahyuni* ${ }^{*}$ Prima Nucifera

Universitas Samudra

Jalan. Prof. Dr. Syarief Thayeb, Meurandeh, Kota Langsa - Aceh - 24416

${ }^{*}$ Corresponding Author: ayuwahyuni@unsam.ac.id

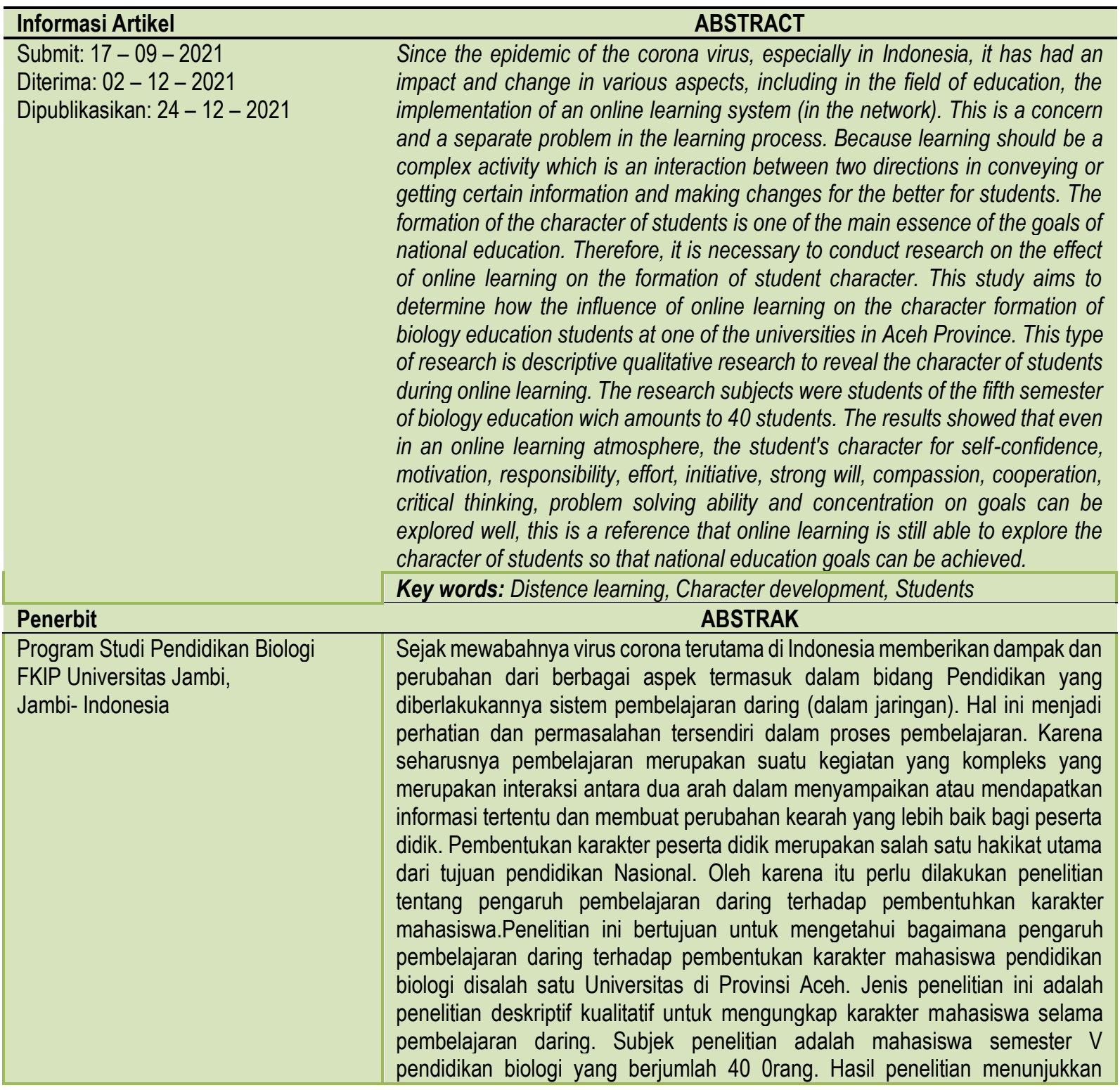


bahwa meskipun dalam suasana pembelajaran daring karakter mahasiswa untuk percaya diri, motivasi, tanggung jawab, usaha, inisiatif, kemauan kuat, kasih sayang, kerjasama, berpikir kritis, kemampuan memecahkan masalah dan konsentrasi pada tujuan dapat tergali dengan baik, hal ini menjadi acuan bahwa pembelajaran secara daring tetap mampu menggali karakter peserta didik sehingga dapat tercapai tujuan pendidikan nasional.

Kata kunci: Pembelajaran daring, Pengembangan karakter, Peserta didik

This BIODIK : Jurnal IImiah Pendidikan Biologi is licensed under a CC BY-NC-SA (Creative Commons Attribution-ShareAlike 4.0 International License)

\section{PENDAHULUAN}

Sejak mewabahnya virus corona terutama di Indonesia memberikan dampak dan perubahan dari berbagai aspek, baik itu dari segi ekonomi, sosial, termasuk dalam bidang pendidikan juga sangat besar pengaruh dan perubahannya. Dalam bidang pendidikan saat ini diberlakukan sistem pembelajaran daring (dalam jaringan). Dalam Kamus Besar Indonesia diartikan dalam jaringan, terhubung melalui jejaring komputer, internet, dan sebagainya (Santika, 2020). Pembelajaran daring ini dilaksanakan sebagai langkah tepat untuk dapat mencegah dan menekan penularan virus Covid-19, peserta didik diharapkan tidak akan ketinggalan pembelajaran sebagaimana yang telah direncanakan dalam kurikulum yang telah ditentukan. Dimana seluruh kegiatan pembelajaran tidak lagi berlangsung secara langsung atau tatap muka. Meskipun kenyataan pada pelaksanaan pembelajaran selama daring, KKM tidak tercapai secara maksimal, terdapat beberapa permasalahan diantaranya pengawasan sulit dilakukan, motivasi anak turun, kemudian banyak keluhan guru dimana peserta didiknya bermain game dan ada pula orang tua yang mengerjakan tugas sekolah anaknya, sehingga nilai anak-anak menjadi tidak terukur. Hal ini merupakan beberapa contoh hambatan dalam pembelajaran daring, karena guru atau dosen pun tidak dapat mengontrol sepenuhnya kegiatan masing-masing peserta didiknya dirumah. Untuk pembelajaran daring ini membutuhkan dampingan dan kerja sama dari orang tua/wali dari peserta didik untuk dapat memantau perkembagan dan pembelajaran anak elama belajar daring dirumah, sehingga tujuan pembelajaran dapat terlaksana dengan baik.

Semua pelaksanaan kegiatan belajar mengajar (KBM) dilakukan dengan sistem pembelajaran daring dengan menggunakan berbagai media online seperti WhatsApp Group, Google Classroom, Zoom Meeting, Google meat, dll. Keseluruhan media pembelajaran itu memiliki kelemahan dan kelebihan tersendiri untuk pelaksanaan proses pembelajaran. Hal ini menjadi perhatian dan permasalahan tersendiri dalam proses pembelajaran. Karena seharusnya pembelajaran merupakan suatu kegiatan yang kompleks yang merupakan interaksi antara dua arah dalam menyampaikan atau mendapatkan informasi tertentu dan membuat perubahan kearah yang lebih baik bagi peserta didik. Perubahan tersebut dapat diartikan sebagai segala sesuatu yang tidak diketahui menjadi sesuatu yang diketahui, dan sesuatu yang belum baik berubah menjadi lebih baik.

Salah satu makna dari sesuatu yang belum baik menjadi baik adalah dalam hal pembentukan karakter peserta didik. Karakteristik peserta didik didefinisikan sebagai ciri dari kualitas perorangan peserta didik yang ada pada umumnya meliputi antara lain kemampuan akademik, usia dan tingkat kedewasaan, motivasi terhadap mata pelajaran, pengalaman, ketrampilan, psikomotorik, kemampuan 
kerjasama, serta kemampuan sosial (Suparman, 2001). Degeng (1991) mengatakan bahwa karakteristik siswa adalah aspek-aspek atau kualitas perseorangan siswa yang telah dimilikinya. Menganalisis karakteristik siswa ini bertujuan untuk mengetahui ciri-ciri perseorangan siswa. Menurut T. Ramli (2003), pendidikan karakter memiliki esensi dan makna yang sama dengan pendidikan moral dan pendidikan akhlak yang bertujuan untuk membentuk pribadi anak, supaya menjadi manusia yang baik, warga masyarakat, dan warga negara yang baik. Pendidikan karakter merupakan penciptaan lingkungan sekolah yang membantu siswa dalam perkembangan etika, tanggung jawab melalui model, dan pengajaran karakter yang baik melalui nilai-nilai universal (Berkowitz \& Bier, 2005:7). Untuk itu pendidikan karakter merupakan hal yang sangat penting bagi peserta didik dan merupakan pondasi bagi peserta didik untuk menjadi manusia yang memiliki kepribadian yang baik.

Pembentukan karakter ini merupakan salah satu hakikat utama dari tujuan pendidikan Nasional. Menurut Kholifah (2020) Pendidik harus dapat mengajarkan, mendidik, dan melatih peserta didik di Indonesia agar menjadi anak yang berkarakter seperti tuntutan pendidikan saat ini. Pendidikan karakter dapat kita terapkan pada pembelajaran daring, akan tetapi para pendidik tentu tidak dapat dengan maksimal menanamkan nilai-nilai karakter yang baik pada peserta didik secara maksimal karena keterbatasan dari berbagai segi dalam pelaksanaan pembelajaran daring ini. Guru atau pendidik harus berusaha menjalin komunikasi yang intens dengan peserta didik meskipun tidak dapat bertatap muka secara langsung, agar tetap dapat memahami karakter peserta didiknya, meskipun hal ini sulit dilakukan dan merupakan hambatan besar dalam pembelajaran daring yakni mengenai komunikasi itu sendiri, akan tetapi pendidikan karakter merupakan esensi yang penting dan perlu ditanamkan pada peserta didik, meskipun dalam sistem pembelajaran daring. Hal ini sesuai dengan Komitmen Nasional tentang perlunya pendidikan karakter, secara imperatif tertuang dalam Undang-undang Nomor 20 Tahun 2003 tentang Sistem Pendidikan Nasional, dalam Pasal 3 UU tersebut dinyatakan bahwa "Pendidikan Nasional berfungsi mengembangkan kemampuan dan membentuk watak serta peradaban bangsa yang bermartabat dalam rangka mencerdaskan kehidupan bangsa, bertujuan untuk berkembangnya potensi peserta didik agar menjadi manusia yang beriman dan bertakwa kepada Tuhan Yang Maha Esa, berakhlak mulia, sehat, berilmu, cakap, kreatif, mandiri, dan menjadi warga negara yang demokratis serta bertanggung jawab (Asriati, 2012). Berdasarkan penelitian yang dilakukan oleh Santika (2020) pada pembelajaran daring ini dapat memberikan kesempatan bagai peserta didik dalam mengaktualisasikan nilai-nilai karakter di masyarakat dalam upaya keikutsertaan pencegahan dan penanggulangan Covid-19. Sedangkan dalam pembelajaran selama pendemi, pendidikan karakter dapat digali dengan menggunakan berbagai strategi pembelajaran diantaranya dapat melalui multiple intelligences berbasis portofolio.

Sejalan dengan pentingnya pendidikan karakter yang sesuai dengan tujuan Nasional, pendidikan karakter tersebut mengajarkan kebiasaan cara berpikir dan berperilaku sehingga mahasiswa atau peserta didik mampu hidup dan bekerjasama dengan keluarga, masyarakat, negara, dan membantu mereka dalam membuat keputusan yang tepat. Karena pendidikan karakter tidak bisa dibentuk secara instan maka mahasiswa harus dilatih secara serius, berkelanjutan dan seimbang untuk mencapai karakter yang ideal (Susanti, 2013). Kemudian pendidikan karakter menentukan cara berpikir dan berperilaku seseorang. Karakter yang baik dapat memberikan dorongan untuk berbuat baik, menyetujui seseorang yang setiap saat berbuat baik atau memiliki budi pekerti luhur (Supriadi, 2020).Dari hasil penelitian Yoga Purandina dan Astra Winaya (2020) menyatakan bahwa perkembangan dari nilai 
karakter tersebut, ialah perubahan yang besar dalam perkembangan karakter peserta didik. Karakter yang baik akan menjadikan anak memiliki masa depan yang lebih cerah nantinya ketika mereka akan tumbuh dan berkembang apalagi dirumah dimana kedua orang tua terlibat dalam mengajari anaknya nilai-nilai karakter itu sendiri.Penelitian dariPurnomo dan Wahyudi (2020) menghasilkan kesimpulan bahwa nilai pendidikan karakter yang diharapkan dari peserta didik yaitu rasa menghargai perbedaan agama dan kepercayaan, berpendirian, toleransi beragama dan tidak memaksakan kehendak, dan anti perundungan.

Lalu bagaimana dengan pembentukan karakter peserta didik dalam proses pembelajaran daring seperti saat ini? apakah sistem pembelajaran daring dapat membentuk karakter peserta didik? Hal ini menjadi perhatian peneliti untuk mengamati pengaruh pembelajaran daring terhadap pembentukan karakter mahasiswa dimasa pandemi. Karena dapat disebutkan bahwa, mahasiswa dengan karakter yang kuat pada akhirnya akan meningkatkan mutu pendidikan nasional (Sukmawati, 2016). Oleh karenaituperludilakukanpenelitiantentangpengaruh pembelajaran daring terhadap pembentukan karakter mahasiswa.Penelitianinibertujuanuntukmengetahuibagaimana pengaruh pembelajaran daring terhadap pembentukan karakter mahasiswa pendidikan biologi disalah satu Universitas di Provinsi Aceh.

\section{METODE PENELITIAN}

Jenis penelitian ini adalah penelitian deskriptif kualitatif untuk mengungkap karakter mahasiswa selama pembelajaran daring. Subjek penelitian adalah mahasiswa semester $\mathrm{V}$ pendidikan biologi Universitas Samudra. Teknik pengumpulan data yang digunakan dalam penelitian ini melalui instrumen pengembangan karakter dengan 10 indikator dalam menggali karakter peserta didik yakni: percaya diri, motivasi, tanggung jawab, usaha, inisiatif, kemauan kuat, kasih sayang, kerjasama, berpikir kritis, kemampuan memecahkan masalah dan konsentrasi pada tujuan. Instrumen dibuat menggunakan skala likert.Instrumen digunakan untuk menjaring data atau informasi yang berkaitan dengan penilaian karakter peserta didik yang timbul selama pembelajaran daring. Data diolah dengan menggunakan program SPSS dengan analisis statistika deskriptif. Instrumen digunakan untuk mengumpulkan data karakter, karena menurut Anderson (2001), karakter merupakan bagian dari ranah afektif yang metode pengumpulan datanya melalui observasi dan metode laporan-diri dengan asumsi bahwa yang mengetahui keadaan afektif (karakter) seseorang adalah dirinya sendiri.

\section{HASIL PENELITIAN DAN PEMBAHASAN}

Dari hasil data yang diperoleh, dapat disimpulkan bahwa pada indikator percaya diri didapatkan hasil bahwa selama pembelajaran daring, $50 \%$ mahasiswa merasa percaya diri saat guru bertanya pada saat pembelajaran daring dan dalam pengerjaan tugas, hal ini membuktikan bahwa, walaupun pembelajaran daring, sebagian besar mahasiswa merasa sangat percaya diri dengan kamampuannya untuk menghadapi proses pembelajaran. Artinya, pembelajaran daring tidak menghambat rasa percaya diri mahasiswa, hanya 1 orang mahasiswa yang menyatakan bahwa dia tidak percaya diri.

Kemudian dari hasil survei pada indikator motivasi, sebesar 55\% mahasiswa merasa sangat setuju dan $42,5 \%$ mahasiswa merasa setuju bahwa motivasi mereka meningkat pada saat pembelajaran 
daring yakni dengan arahan diberinya motivasi belajar oleh pendidik. Hal ini menjadi perhatian penting bagi pendidik bahwa sangat penting sekali memberikan motivasi kepada mahasiswa agar mereka tetap giat dan semangat mengahadapi pembelajran meskipun tidak bertatap muka secara langsung. Dari hasil survei didapatkan data yang disajikan pada tabel 1 .

Tabel 1. Tampilan Tabel pada Artikel

\begin{tabular}{|c|c|c|}
\hline Indikator & Persentase positif responden & $\begin{array}{l}\text { Kategori perkembangan } \\
\text { karakter }\end{array}$ \\
\hline Percaya diri & $50 \%$ & Baik \\
\hline Motivasi & $55 \%$ & Baik \\
\hline Tanggung jawab & $55 \%$ & Baik \\
\hline Usaha & $57,5 \%$ & Baik \\
\hline Inisiatif & $62,5 \%$ & Baik \\
\hline Kemauan kuat & $77,5 \%$ & Sangat Baik \\
\hline Kasih sayang & $60 \%, 70 \%$ & Baik \\
\hline Kerjasama & $52,5 \%$ & Baik \\
\hline Berpikir kritis & $50 \%$ & Baik \\
\hline Kemampuan memecahkan masalah & $67,5 \%$ & Baik \\
\hline Konsentrasi pada tujuan & $40 \%$ & Cukup \\
\hline
\end{tabular}

Untuk indikator tanggung jawab menunjukkan bahwa 55\% mahasiswa memiliki tanggung jawab selama pembelajaran daring yakni dengan tidak mengabaikan kedisiplinan pada saat pembelajaran daring. Kedisiplinan merupakan hal yang penting untuk memumupuk tanggung jawab mahasiswa, agar kelak nanti memiliki karakter yang bertanggung jawab dengan tidak mengabaikan pentingnya waktu. Namun pada indikator usaha, didapat data bahwa $57,5 \%$ mahasiswa ragu-ragu untuk menyatakan bahwa mereka tidak pernah menyontek dibuku/internet pada saat mengerjakan tes daring, hal ini berdasarkan jawaban mahasiswa yang diharapkan memberikan jawaban yang sesungguhnya. Kesimpulan dari data bahwa, selama pembelajaran daring rata-rata mahasiswa berusaha untuk menjawab tes dengan menyontek pada buku/internet.

Kemudian pada saat pembelajaran daring, kemauan yang kuat pada mahasiswa dapat tergali pada saat mereka mencari jaringan internet pada saat pembelajaran daring yakni sekitar $77,5 \%$ sangat setuju untuk mencari jaringan yang baik pada saat pembelajarn daring. Dan indikator kasih sayang menunjukan $60 \%$ mahasiswa merasa setuju memberikan apresiasi berupa senyuman atau tepuk tangan ketika teman sekelasnya dipuji oleh dosen pada saat pembelajaran daring dan $70 \%$ mahasiswa tidak mengejek temannya yang melakukan kesalahan pada saat pembelajaran daring.

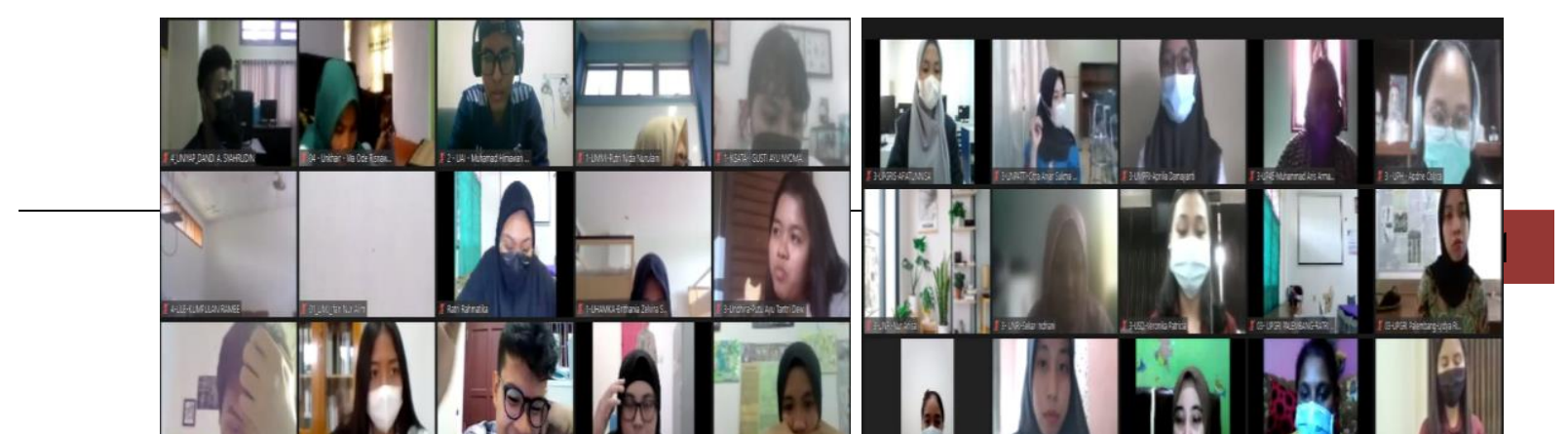




\section{Gambar 1. Suasana pembelajaran daring pada mahasiswa (sumber: zoom meeting)}

Indikator kerjasama dan berpikir kritis pun dapat tergali dalam pembelajaran daring dengan persentase $47,4 \%$ mahasiswa sangat setuju untuk tetap bertanya pada guru maupun teman lainnya pada saat pembelajaran daring dan $67,5 \%$ mahasiswa setuju mengajak teman yang lainnya berdiskusi bersama dalam memecahkan permasalahan. Kemudian, konsentrasi mahasiswa dalam pembelajaran daring tetap berjalan baik, dengan persentase $40 \%$ mahasiswa tidak setuju untuk tidak memperhatikan pembelajaran yang sedang diajarkan dalam pembelajaran daring, artinya, mahasiswa memperhatikan pembelajaran yang sedang diajarkan dalam pembelajarn daring.

Sesuai dengan hasil survei yang didapatkan ini dapat diambil kesimpulan bahwa karakter dapat terbentuk melalui proses berpikir seseorang yang akan menuntunnya mengambil sikap. Sikap yang diputuskan akan memotivasinya kepada suatu tindakan yang dilakukan secara konsisten dan terusmenerus, sehingga menjadi kebiasaan (Suyanto, 2009). Hal ini dapat dilihat dari hasil pembelajaran daring yang telah berlangsung selama 3 semester perkuliahan yang tidak banyak mengubah karakter mahasiswa semester $\mathrm{V}$ sehingga karakter yang terbentu masih tergolong baik.

Untuk itu pembelajaran daring bisa menjadi modal awal bagi peserta didik untuk meningkatkan dirinya karena peserta didik dituntut untuk mandiri dikemudian hari. (Nasution, Neviyarni and Alizamar, 2017) dengan android, peserta didik bisa bertanya dengan teman tentang tugas sekolah yang rumit untuk mereka pahami, berdiskusi tentang tugas besok, memberikan kabar jika tidak bisa datang kesekolah, dan sangat banyak hal yang bisa mereka bahas dengan android. Itulah nantinya yang akan membentuk karakter peserta didik yang mandiri karena mereka juga akan di tuntut untuk berusaha demi kepentingan diri mereka pribadi, kemandirian serta kepedulian mahasiswa diharapkan akan tetap berkembang baik selama pembelajaran daring.

\section{SIMPULAN}


Dari keseluruhan indikator yang diukur dapat diambil kesimpulan bahwa meskipun dalam suasana pembelajaran daring karakter mahasiswa untuk Percaya diri, Motivasi, Tanggung jawab, Usaha, Inisiatif, Kemauan kuat, Kasih sayang, Kerjasama, Berpikir kritis, Kemampuan memecahkan masalah dan Konsentrasi pada tujuan dapat tergali dengan baik. Akan tetapi hal ini didukung oleh beberapa faktor eksternal yang menentukan karakter ini dapat tergali. Diantaranya yakni tersedianya jaringan internet yang baik sehingga mahasiswa dengan mudah mengakses internet untuk dapat mengikuti jalannya pembelajran meskipun dengan sistem daring. Kemudian, dalam pembelajaran daring dosen atau pendidik juga diharapkan mampu memberikan motivasi dan semangat kepada mahasiswa agar dapat dengan baik mengikuti pembelajran meskipun dengan berbagai keterbatasan yang ada. Hal ini sejalan dengan pernyataan Santika (2020) yang menyatakan bahwa secara garis besar komponen yang harus dipersiapkan oleh pendidik sebagai infrastruktur dalam pembelajaran daring adalah ketersediaan jaringan internet, menyiapkan strategi pembelajaran, menyiapkan konten belajar (efek, gambar, audio, vidio dan simulasi), menyediakan learning management system (google classroom, zoom, jitsi, webex, dII) dan pada dasarnya keberhasilan proses pembelajaran daring memerlukan sinergitas antara pemerintah, satuan pendidikan, guru, peserta didik tentunya peran orang tua dan lingkungan peserta didik untuk dapat mendukung keberhasilan proses pembelajaran daring tersebut. Kemudian selain kompenen yang disebutkan diatas, membentuk karakter dalam perspektif pembelajaran tidak bisa dilepaskan dari pilihan strategi di dalam kelas. Semakin tepat strategi yang dipilih akan semakin memperkuat dan mempercepat transformasi nilai-nilai ke dalam diri individu-individu dan akhirnya masyarakat (Manurung, 2017).Pada bagian ini, hindari dalam bentuk point per point. Simpulan harus diuraikan dalam bentuk satu paragraf. Simpulan harus dirumuskan secara konseptual dan berorientasi pada penjelasan temuan penelitian yang spesifik serta dikuatkan dengan data hasil penelitiannya.

\section{UCAPAN TERIMA KASIH}

Penelitian ini dapat terlaksana dengan baik berkat bantuan dari berbagai pihak. Terimakasih penulis ucapkan kepada seluruh dosen yang terlibat dalam pembuatan artikel ini, baik dalam bentuk dukungan maupun masukan. Kemudian terimakasih kepada pinpinan universitas samudra. Penulis juga mengucapkan terimakasih kepada seluruh mahasiswa yang telah berpartisipasi menjadi subjek dalam penelitian ini. penelitian ini didedikasikan khusus untuk pendidikan Indonesia.

\section{RUJUKAN}

Anderson, L., and Krathwohl, D. (eds.) (2001). Assessing: A Revision of Bloom's Taxonomy. New York: Publishing Co, New York, US.

Asriati, Nuraini. 2012. Mengembangkan Karakter Peserta Didik Berbasis Kearifan Lokal Melalui Pembelajaran Disekolah. Jurnal Pendidikan Sosiologi dan Humaniora. Vol. 3. No.2.

Berkowitz, M.W. \& Bier, M.C. 2005. What Works In CharacterEducation: A Research-Driven Guide for Educators, Washington DC: Univesity of Missouri-St Louis.

Degeng, N.S. 1991. Karakteristik Belajar Mahasiswa Berbagai Perguruan Tinggi di Indonesia. Jakarta: Depdikbud Dirjen Dikti Proyek Pengembangan Pusat Fasilitas Bersama Antar Universitas/IUC

Kholifah, WT. 2020. Upaya Guru Mengembangkan Karakter Peserta Didik Sekolah Dasar Melalui Pendidikan Ramah Anak. Jurnal Pendidikan Dan Konseling Vol. 2. No. 1. 
Manurung, Monica.M, Rahmadi.2017. Identifikasi Faktor-faktor Pembentukan Karakter Mahasiswa. Jurnal Analisis Sistem Pendidikan Tinggi. Vol. 1 No. 1

Nasution, J. A., Neviyarni, N. and Alizamar, A. (2017) 'Motif Siswa memiliki Smartphone dan Penggunaannya', JPPI (Jurnal Penelitian Pendidikan Indonesia), 3(2), p. 15. doi: 10.29210/02017114.

Purnomo, E. and Wahyudi, A. B. (2020) 'Nilai Pendidikan Karakter dalam Ungkapan Hikmah di SD seKaresidenan Surakarta dan Pemanfaatannya di Masa Pandemi', QALAMUNA: Jurnal Pendidikan, Sosial, dan Agama, 12(2), pp. 183-193. doi: 10.37680/qalamuna.v12i2.561.

Ramli. T., 2003. Pendidikan Karakter. Bandung:Angkasa

Santika, I. W. E. 2020. Pendidikan Karakter pada Pembelajaran Daring. Indonesian Values and Character Education Journal. Vol 3. No. 1.

Suparman, Atwi. 2001. Mengajar Di Perguruan Tinggi(Konsep Dasar Pengembangan Kurikulum). Departemen Pendidikan Nasional.

Supriadi, Wildan., \& Laksmiwati, D. 2020. Implementasi Model Pembelajaran Berbasis Masalah dan Pengaruhnya Terhadap Perkembangan Karakter Mahasiswa. Jurnal Penelitian Pendidikan IPA (JPPIPA). 6(1). pp. 63-68

Susanti R, 2013, Penerapan Pendidikan Karakter di Kalangan Mahasiswa, Jurnal Al-Ta'lim, 1(6) November 2013, HIm. 480-487

Suyanto. 2009. Urgensi Pendidikan Karakter. Diakses pada tanggal 10 April 2011 dari http://www.mandikdasmen.depdiknas.go.id/we/ pages/urg ensi.html.

Yoga Purandina, I. P. and Astra Winaya, I. M. (2020) 'Pendidikan Karakter di Lingkungan Keluarga Selama Pembelajaran Jarak Jauh pada Masa Pandemi COVID-19', Cetta: Jurnal IImu Pendidikan, 3(2), pp. 270-290. doi: 10.37329/cetta.v3i2.454. 